\title{
Allostatic Load and Its Impact on Health: A Systematic Review
}

\author{
Jenny Guidi ${ }^{a}$ Marcella Lucente ${ }^{a}$ Nicoletta Sonino $^{b, c}$ Giovanni A. Fava ${ }^{c}$ \\ ${ }^{a}$ Department of Psychology, University of Bologna, Bologna, Italy; ${ }^{b}$ Department of Statistical Sciences, University of \\ Padova, Padova, Italy; ' Department of Psychiatry, State University of New York at Buffalo, Buffalo, NY, USA
}

\section{Keywords}

Allostatic load · Allostatic overload · Biomarkers .

Clinimetrics · Diagnostic Criteria for Psychosomatic

Research $\cdot$ Stress

\begin{abstract}
Introduction: Allostatic load refers to the cumulative burden of chronic stress and life events. It involves the interaction of different physiological systems at varying degrees of activity. When environmental challenges exceed the individual ability to cope, then allostatic overload ensues. Allostatic load is identified by the use of biomarkers and clinical criteria. Objective: To summarize the current knowledge on allostatic load and overload and its clinical implications based on a systematic review of the literature. Methods: PubMed, PsycINFO, Web of Science, and the Cochrane Library were searched from inception to December 2019. A manual search of the literature was also performed, and reference lists of the retrieved articles were examined. We considered only studies in which allostatic load or overload were adequately described and assessed in either clinical or non-clinical adult populations. Results: A total of 267 original investigations were included. They encompassed general population stud-
\end{abstract}

ies, as well as clinical studies on consequences of allostatic load/overload on both physical and mental health across a variety of settings. Conclusions: The findings indicate that allostatic load and overload are associated with poorer health outcomes. Assessment of allostatic load provides support to the understanding of psychosocial determinants of health and lifestyle medicine. An integrated approach that includes both biological markers and clinimetric criteria is recommended.

(c) 2020 S. Karger AG, Basel

\section{Introduction}

The concept of allostatic load was introduced by McEwen and Stellar in 1993 [1] and refers to the cost of chronic exposure to fluctuating or heightened neural and neuroendocrine responses resulting from repeated or chronic environmental challenges that an individual reacts to as being particularly stressful. It derives from the definition of allostasis as the ability of the organism to achieve stability through change [2], and the view that healthy functioning requires continual adjustments of the internal physiological milieu [3].

karger@karger.com

www.karger.com/pps

(c) 2020 S. Karger AG, Basel

Karger"
Jenny Guidi

Department of Psychology, University of Bologna

Viale Berti Pichat 5

IT-40127 Bologna (Italy)

jenny.guidi2@ unibo.it 
Table 1. Clinical criteria for allostatic overload (A through B are required)

\begin{tabular}{l} 
Criterion A $\begin{array}{l}\text { The presence of a current identifiable source of distress in the form of recent life events and/or chronic stress; the } \\
\text { stressor is judged to tax or exceed the individual coping skills when its full nature and full circumstances are evaluated }\end{array}$ \\
\hline Criterion B \\
$\begin{array}{l}\text { The stressor is associated with one or more of the following features, which have occurred within } 6 \text { months after the } \\
\text { onset of the stressor: }\end{array}$ \\
1. At least two of the following symptoms: difficulty falling asleep, restless sleep, early morning awakening, lack of \\
2. Significant impairment in social or occupational functioning \\
3. Significant impairment in environmental mastery (feeling overwhelmed by the demands of everyday life)
\end{tabular}

The definition of allostatic load $[1,4,5]$ reflects the $\mathrm{cu}-$ mulative effect of experiences in daily life that involve ordinary events (subtle and long-standing life situations) as well as major challenges (life events), and also includes the physiological consequences of the resulting healthdamaging behaviors, such as poor sleep and circadian disruption, lack of exercise, smoking, alcohol consumption and unhealthy diet. When environmental challenges exceed the individual ability to cope, then allostatic overload ensues $[3,6]$ as a transition to an extreme state where stress response systems are repeatedly activated and buffering factors are not adequate [7].

Situations that may lead to the development of allostatic load/overload are: (a) exposure to frequent stressors that may determine a status of chronic stress and repeated physiological arousal; (b) lack of adaptation to repeated stressors; (c) inability to shut off the stress response after a stressor is terminated; (d) allostatic response not sufficient to deal with the stressor $[8,9]$.

In response to environmental demands, different physiological systems interact at varying degrees of activity [1]. The neuroendocrine and immune systems respond to internal or external challenges and promote adaptation to threats or adversities $[5,8]$. The hypothalamic-pituitary-adrenal axis plays a key role in the pathophysiology of allostatic load $[5,10]$. Brain architecture and neurochemical functions are affected by both genomic and nongenomic mechanisms [11, 12]. Adjustments in the immune system (e.g., leukocytes, cytokines, inflammation) do occur, with immunosuppressive effects in the long run [13]. Alterations in body functions involving cardiovascular and gastrointestinal systems, endocrine-metabolic balances and sleep may ensue $[5,10,14$, 15].

Characterization of allostatic load has been carried out by two distinct approaches. One is concerned with the use of biomarkers that reflect physiological derangements; the other is a clinical approach targeted to the more severe end of the spectrum of associated symptomatology, subsumed under the rubric of allostatic overload.

Several studies have focused on identifying allostatic load through biological markers [5, 7, 14, 16-25]. Seeman et al. $[16,17]$ identified 10 biological parameters: cortisol, dehydroepiandrosterone (DHEA), epinephrine, norepinephrine, cholesterol, glycosylated hemoglobin, resting systolic and diastolic blood pressure, body mass index, and waist-hip ratio. The first four parameters have been considered as primary mediators of allostatic load because of their immediate correlation with adrenal function, whereas the remaining parameters were defined as secondary mediators $[16,17]$. Biological markers of diseases resulting from a condition of allostatic load were defined as tertiary mediators [26]. Additional biomarkers (glucose levels, lipid profiles, interleukin-6, heart rate variability) have subsequently been recognized as having a role in the allostatic load response and were then included in a cumulative index of allostatic load, commonly known as the "allostatic load battery" $[14,17,27]$. This index of allostatic load was found to be a better predictor of mortality and decline in physical functioning than individual biomarkers alone [28-31], yet a number of limitations emerged due to the complexity and dynamic nature of this multisystem network [22].

While the biological perspective does not allow for a comprehensive understanding of allostatic load and overload and related clinical phenomena, a substantial contribution has come from clinimetrics, the science of clinical measurements $[32,33]$. Clinimetric criteria for the determination of allostatic overload and the underlying experiential factors (Table 1), as well as a semi-structured interview, have been developed $[6,34]$ and included in the Diagnostic Criteria for Psychosomatic Research (DCPR) [35]. The interview can be supplemented by the PsychoSocial Index (PSI) [36, 37], a simple self-rated questionnaire, tailored to a busy clinical setting, for a comprehensive assessment of stress, psychological distress, abnor-
Guidi/Lucente/Sonino/Fava 
mal illness behavior and well-being. The PSI may provide a quantitative measurement of the degree of allostatic load, with opportunity to monitor its course over time. Use of cut-off points for identifying allostatic overload is also possible $[36,37]$. The interview and the PSI may contribute to formulating a global clinical judgment of individual assets and coping skills in dealing with current life situations. The clinimetric evaluation of allostatic overload may help identify a state that, by exceeding individual resources, could constitute a danger to health. Unlike in the DSM-5 diagnosis of adjustment disorder [38], the presence of a psychiatric disorder is not a source of exclusion from the criteria.

With this systematic review we try to summarize the current knowledge on allostatic load/overload and its clinical implications. Previous systematic reviews $[29,30$, $39,40]$ were concerned with specific aspects such as health disparities, workforce, socioeconomic position and psychosocial resources.

\section{Methods}

Search Strategy

The methods used fulfilled the PRISMA guidelines [41]. Published articles concerning allostatic load/overload were identified by searching in PubMed, PsycINFO, Web of Science, and the Cochrane Library from inception to December 2019. Search terms included "allostatic load" or "allostatic overload." Only published articles in the English language and involving human subjects were considered for inclusion. A manual search of the literature was also performed, and reference lists of the retrieved articles were examined for further studies not yet identified.

\section{Study Selection}

We considered only those studies in which allostatic load or overload were adequately described and assessed in either clinical or non-clinical adult populations. Biological evaluation of allostatic load should be based on at least 3 biological markers. Allostatic overload was determined according to clinimetric criteria. Studies involving pediatric or adolescent populations were excluded.

\section{Data Extraction}

The first two authors (J.G. and M.L.) independently performed the search, screened titles and abstracts, assessed the full text of articles appearing potentially relevant, and selected studies meeting the eligibility criteria. In case of disagreement, a consensus was reached through discussion with the senior authors (N.S. and G.A.F).

\section{Data Synthesis}

All selected original investigations were reported in the systematic review. Other studies (e.g., articles not primarily focused on allostatic load and studies not involving adults) were not included. The most relevant reviews were cited in the introduction and discussion.

Allostatic Load and Health

\section{Results}

The initial search strategy provided 3,633 published articles that were screened for potential inclusion in the review (online suppl. Fig. S1; for all online suppl. material, see www.karger.com/doi/10.1159/000510696). A total of 524 full-text articles were assessed for eligibility, 267 of which were included in the systematic review.

\section{General Population Studies}

Sociodemographic Correlates

Several studies focused on the association between sociodemographic variables and allostatic load $[18,19,22$, $23,42-58]$.

Low socioeconomic status was associated with high levels of allostatic load [59-68]. The findings were confirmed by other investigations where high socioeconomic position appeared to be related to low allostatic load $[45,53,69-72]$. Similarly, income level was negatively related to allostatic load in different populations [65, 7376]. Perceived neighborhood quality may have an impact on allostatic load [77, 78], and high levels of allostatic load were reported by individuals living in impoverished [7985] or segregated neighborhoods [86]. Nonetheless, adults who grew up in low socioeconomic status households showed lower levels of allostatic load when adapting to life stressors maintaining a focus on the future [87]. Factors such as renting one's home, having low income, and smoking were found to mediate the association between socioeconomic position and allostatic load [88] and explain socioeconomic disparities in allostatic load [88]. Parental socioeconomic position was found to be inversely associated with midlife allostatic load, and part of this association was mediated by education [89]. In a longitudinal community-based study on a multi-ethnic cohort of midlife women, high racial discrimination and hostility, low income, and low education significantly predicted high allostatic load levels [65].

In some studies, allostatic load was negatively associated with years of education $[61,73,79,90-92]$. However, two investigations $[93,94]$, examining the mediating role of ethnicity in the relationship between allostatic load and educational attainment, found the highest levels of allostatic load among minorities with a college degree or more.

Ethnicity was associated with allostatic load, with Black Americans displaying higher levels of allostatic load compared to Whites [95-99]. Among immigrants, a positive association between allostatic load and duration of residence was found [100-102], whereas studies on age at 
immigration yielded mixed results [101, 102]. The relationship between perceived racial discrimination and allostatic load was found to be mitigated by the effect of educational attainment among African American women [103]. Differential associations between everyday versus institution-specific racial discrimination and allostatic load were found among black women [104]. Furthermore, higher allostatic load was shown by individuals reporting greater perceived racial [105] or social inequalities $[63,106]$, or adversities over the life course $[107,108]$. In addition to perceived racial discrimination $[65,109$ 114], also acculturation stress [115] and weight discrimination $[116,117]$ were found to be associated with high levels of allostatic load.

There was an association between allostatic load and gender-related characteristics (e.g., androgynous and undifferentiated individuals, masculinity levels), as well as sexual orientation (i.e., lesbian, gay, and bisexual individuals) [118-122].

A negative association between allostatic load biomarkers and religious attendance has been reported [123]. Weekly religious service attendance was associated with lower allostatic load in older adults [124-126]. A significant inverse association between church attendance and all-cause mortality risk, partially explained by allostatic load, was also found [127].

\section{Aging}

Several studies have shown an association between allostatic load and frailty, a multidimensional loss of individual resources with aging [128-130]. Evaluation of data from two prospective population-based cohort studies [131] have suggested that several allostatic load parameters could be considered as a preclinical marker of frailty.

Allostatic load was associated with a decline in cognitive and physical functioning in older adults $[16,17,130$, 132-135], changes in brain structure with aging [136], brain-predicted age difference [137], and inversely related to white-matter and brain volume [138]. A potential link between an immune risk phenotype and allostatic load in very old adults was identified [139]. Allostatic load was also found to increase delirium in hospitalized elderly patients [140] and the risk of mortality [141, 142]. Data from a representative longitudinal study on older adults [143] showed that high allostatic load levels were associated with several personality characteristics (neuroticism, lower extroversion, lower conscientiousness) at baseline, and with declines in extroversion, conscientiousness, agreeableness and openness at a 4-year follow-up. Older adults with canine companionship displayed lower levels of allostatic load compared to those without [144].

Data from a large community-based study on participants aged 60 years and over showed a significant association between increased allostatic load levels and worsening of visual acuity, after adjustment for confounders [145]. Further, worse visual acuity increased mortality risk, with a potential mediating effect of allostatic load [145].

\section{Work and Environment}

Several studies showed that high levels of allostatic load were correlated with work-related stress $[108,114$, 146-151], poor quality job [152] and burnout syndrome $[153,154]$, but no significant associations were found in other studies [155-158]. A negative association between allostatic load and heart rate variability in males employed full-time was reported [159]. Allostatic load was related to insufficient recovery from work stress in women [160], job demand and reorganization at workplace $[150,161,162]$, self-employment [163] and effort-reward imbalance that is regarded as the core dimension of the burnout syndrome $[146,164]$. In a study on civil service workers [165], a non-linear, stable association between negative emotional response to major life events and allostatic load was observed.

In two cross-sectional studies, greater vegetated land cover near residence was associated with low allostatic load levels [166, 167]. Conversely, living in an unhealthy environment may have deleterious effects on health. Lead exposure $[168,169]$, perception of pollution [170], dangerous traffic [125], household crowding [171], and environmental riskscapes [172] may contribute to allostatic load increased levels. Furthermore, poor indoor environmental quality could raise allostatic load [173], whereas better housing conditions and satisfaction with own house appeared to reduce allostatic load [125].

\section{Early Life Events}

Adverse childhood experiences, including child abuse and maltreatment, were found to be associated with high levels of allostatic load in adulthood [174-180]; only in one study [181] childhood socioeconomic status and stress exposure in adulthood were found to predict allostatic load, while adverse childhood experiences were not.

Perceived social support across the life span partially mediated the association between child maltreatment and allostatic load in adulthood [182]. As to family environment, some studies reported the association between either harsh parenting in adolescence [183], lower family
Guidi/Lucente/Sonino/Fava 
support [184], or negative family interactions [185, 186] and allostatic load in adulthood. Conversely, emotional and instrumental support in childhood [187], warmth within the family [174], and parental academic involvement [188] appeared to be associated with lower allostatic load in adulthood. Allostatic load in adulthood seems to be related also to avoidant attachment patterns [189] and predicted by adult anxious attachment style [190].

\section{Well-Being and Coping Strategies}

Cross-sectional data derived from a multidisciplinary prospective population-based cohort study showed an inverse association between allostatic load and positive affects, after adjusting for confounders, with a stronger association in women than men [191].

As to well-being dimensions, data from the Midlife in the United States (MIDUS) survey showed that greater purpose in life predicted lower levels of allostatic load at a 10-year follow-up [192], while studies on positive relationships and social support yielded mixed results [50, 193-196]. In a longitudinal study on middle-aged healthy women, allostatic load at baseline was found to be a negative predictor of sense of coherence at a 6-year follow-up [197].

In a cross-sectional analysis of data from a large community-based study on African American adults [198], women, but not men, using disengagement coping styles displayed significantly higher allostatic load scores. Among self-employed individuals, problem-focused coping strategies were negatively associated with allostatic load [163]. Cognitive reappraisal was indirectly associated with lower allostatic load, whereas the tendency to use emotion suppression was indirectly associated with greater allostatic load [199]. Further, a significant inverse association was found between intrinsic capacity (i.e., physical and mental skills acquired and modified throughout life) and allostatic load among older adults [200].

\section{Caregiving}

Caring for an ill and/or disabled person (i.e., caregiving) represents a risk factor for developing allostatic load, which, in turn, may affect individual health status [151]. The number of negative life events among caregivers of patients with Alzheimer disease was found to be related to allostatic load [201]. Caregivers of patients with Alzheimer disease showed higher levels of allostatic load compared to controls, and this association was mitigated by personal sense of mastery [202]. Parents of children with developmental disorders had lower allostatic load when reporting higher positive affects in a controlled study [203].

Allostatic Load and Health

\section{Consequences on Physical Health}

A number of studies addressed the relationship between allostatic load and health status and outcomes [204-208], including chronic conditions [209], disabilities [210], pain $[211,212]$, and mortality $[17,24,56,213-$ 218].

Poor self-rated health, a measure of actual health status as perceived by an individual, was associated with markers of allostatic load, such as increased cytokine levels [219], higher body mass index and worse lipid profiles [220]. A negative association between self-rated health and allostatic load has been documented by other studies [206, 221-223], and ethnicity seemed to play a mediating role [223].

Allostatic load was found to be related to leukocyte telomere length [224]. Levels of vitamin D [225] and serum carotenoid concentrations [226] appeared to be inversely associated with allostatic load.

\section{Lifestyle Habits}

Physical activity was found to be associated with lower allostatic load [227-229], whereas poor sleep quality [230-233], unhealthy diet and overweight [52, 218, 228, 234-239], alcohol consumption [52, 92, 228, 229, 240] and smoking habits [241] were associated with high allostatic load levels.

\section{Cardiovascular Diseases}

Allostatic load was linked to increased risk for cardiovascular diseases, particularly coronary heart disease [242], ischemic heart disease [243] and peripheral arterial disease [244].

A clinimetric evaluation of allostatic overload by specific criteria $[6,34,35]$ was performed in a number of studies in cardiac settings. In outpatients with essential hypertension and coronary heart disease [245], the presence of allostatic overload was characterized by a higher disease-related emotional burden, poor psychosocial functioning and high rates of psychopathology. Similarly, in patients with atrial fibrillation [246], allostatic overload was associated with increased psychological distress (e.g., depressive and anxiety disorders). In a study on patients undergoing implantable cardioverter defibrillator implantation [247], 16.2\% reported moderate allostatic overload, while $4.3 \%$ reported severe allostatic overload. The presence of allostatic overload before implantation was the only significant predictor of subsequent negative cardiac outcomes, including complications and death after implantation. In patients with congestive heart failure, prevalence of allostatic overload was as high as $32.9 \%$ 
[248], with a significant association with hyperglycemia among cardiac risk factors. In essential hypertension, $32.5 \%$ of patients reported allostatic overload and displayed significantly higher levels of psychological distress and a greater prevalence of psychosomatic syndromes [249]. The presence of allostatic overload among hypertensive patients was associated with lower levels of wellbeing and quality of life [249], unlike in a previous study that used different criteria [250].

\section{Diabetes}

Patients with type 2 diabetes experienced higher allostatic load and greater depressive and hostile symptoms compared to controls [251]. They were found to display a disruption of multisystem responses to stress, as indicated by systolic and diastolic blood pressure, heart rate, total cholesterol, salivary cortisol, and plasma IL-6 levels. Similarly, among patients with type 2 diabetes, allostatic load was associated with high systolic and diastolic blood pressure, and glycated hemoglobin [252].

\section{Gynecology and Obstetrics}

There was an association between early age at menarche, retrospectively ascertained, and allostatic load [253].

Allostatic load in early pregnancy was significantly higher in a sample of women with preeclampsia compared to controls, suggesting a possible role of chronic stress in the development of this condition [254]. Although some studies reported that allostatic load among pregnant women may contribute to adverse pregnancy and birth outcomes [255-257], research findings appear to be rather controversial $[81,258,259]$.

Musculoskeletal Disorders

In a cross-sectional study, greater allostatic load levels were associated with lower spine bone mineral density and lower femoral neck strength values [260].

Symptom frequency and intensity were associated with higher levels of allostatic load among chronic fatigue syndrome patients compared to controls [261-263]. In this condition, polymorphisms in angiotensin-1-converting enzyme linked to allostatic load were reported [264].

A recent preliminary study on female outpatients with fibromyalgia found a prevalence allostatic overload, based on clinimetric criteria, as high as $25 \%$ of the sample [265].

\section{Neurological Disorders}

Depressive symptoms after traumatic brain injury appeared to be related to chronic stress [266] and perceived stress [267]. In a sample of individuals with a first unprovoked seizure or newly diagnosed epilepsy, allostatic load was associated with a higher risk of seizures [268].

In a recent study [269], allostatic overload based on clinimetric criteria was one of the most frequent psychosomatic diagnoses among patients with either episodic or chronic migraine.

\section{Cancer}

Women with breast and ovarian cancer displayed elevated basal cortisol levels and decreased acute cortisol reactivity compared to healthy controls [270]. Among patients with breast cancer, black women reported higher levels of allostatic load compared to both white patients and control subjects [271], after adjusting for confounders. Allostatic overload was more common among cancer survivors (52\%) than healthy controls (33\%) [272].

A randomized controlled trial reported the clinical utility of a mentor-based supportive-expressive program designed to help women with metastatic breast cancer, that obtained significant improvements in allostatic load parameters as well as in affective symptoms and quality of life [273].

\section{Periodontal Diseases}

Data from a large community-based investigation [243] and a subsequent study [274] provided support for the association between allostatic load and periodontal diseases. Further, children of mothers with increased allostatic load were significantly more likely to have dental caries, suggesting the role of maternal stress in child oral health [275].

\section{Consequences on Mental Health}

A clinimetric assessment in the general population [276] revealed that subjects with allostatic overload had significantly higher levels of self-rated stress, psychological distress and abnormal illness behavior than those without. The clinimetric criteria for allostatic overload were able to discriminate the presence of psychological distress in another sample of the general population as well [277]. In a primary care setting [278], allostatic overload was the most frequently reported psychosomatic syndrome according to the DCPR [35]; it was associated with significantly greater psychological distress, lower well-being and impaired quality of life.

\section{Mood and Anxiety Disorders}

Several studies showed a significant association between depressive and anxiety symptoms and allostatic
16

Psychother Psychosom 2021;90:11-27 DOI: $10.1159 / 000510696$
Guidi/Lucente/Sonino/Fava 
load [279-283], not confirmed by others [233, 284-286]. In the association between childhood physical abuse and depression in adulthood, allostatic load appeared to have a mediating role [287]. In a prospective study [288], reaction time in adolescence was found to be predictive of depressive symptoms in adulthood, with a mediating effect of cumulative allostatic load. Data from a large community-based study showed that high allostatic load was more strongly associated with depression among white women and black men than among their respective counterparts, with differences across gendered race groups [282]. In emergency patients primarily diagnosed with mood or anxiety disorders [283], higher levels of allostatic load were found than in those diagnosed with personality disorders.

In a study on older adults, higher levels of allostatic load were associated with both affective and somatic depressive symptoms [280] and were prospectively associated with depressive symptoms at a 3-year follow-up in another [279]. Among older euthymic bipolar disorder patients [289], allostatic load was found to be associated with delayed memory performance.

Post-Traumatic Stress Disorder

Allostatic load helped to understand the association between maternal post-traumatic stress disorder (PTSD) and birth outcomes (i.e., pregnancy complications, preterm birth) [290]. Mothers of pediatric cancer survivors were found to display significantly higher levels of allostatic load compared to control mothers of healthy children, and those meeting criteria for PTSD reported the highest allostatic load levels [291, 292]. In adults with early life traumas, neuroendocrine biomarkers of allostatic load were significantly related to early life stress and subsequent PTSD development [293]. In a study on women veterans reporting multiple sexual assaults during childhood and civilian and military life, higher allostatic load levels were detected compared to women reporting sexual assault in only one life circumstance [294].

\section{Psychotic Disorders}

Allostatic load was associated with cortical thickness [295] and fornix microstructure [296] in schizophrenic patients. It seemed to have a role early in the course of schizophrenia and in greater severity of positive psychotic symptoms in its early stages [297], as well as in the chronic course of the disease [298]. Accordingly, higher levels of allostatic load were found in patients at their first psychotic episode [299, 300] and at acute relapse of schizophrenia [301] compared to control subjects. Allo- static load appeared to be inversely related to psychosocial [299] and cognitive functioning [301] in psychotic patients.

\section{Alcohol Dependence}

The combined contribution of hypothalamic-pituitary-adrenal reactivity and environmental stressors to relapse severity in alcohol-dependent men following treatment was investigated [302]. Greater levels of ongoing life stress strengthened the relationship between adrenocortical sensitivity and post-treatment drinking. Environmental stressors increased relapse intensity [302].

\section{Discussion}

Most research on allostatic load relies on biomarkers that express a state of body systems, but do not provide information on the underlying individual causes. Moreover, substantial heterogeneity exists across studies as to the type and number of parameters to be considered. It seems that use of clinimetric tools can increase the number of people screened, set the use of biomarkers in a clinical context, and broaden dissemination of measures to prevent or decrease the negative impact of toxic stress on health.

The findings indicate that higher allostatic load and overload are associated with poorer health outcomes in both general and clinical populations. The results provide support to the clinical utility of the trans-diagnostic identification of allostatic load and overload in a variety of settings, with a number of potential applications.

Consideration of allostatic load may increase the predictive power of the assessment procedure and may contribute to the understanding of many symptoms that are commonly encountered in clinical practice, but that, in a predominantly disease focused model, fail to receive adequate attention and care [303, 304]. Clinical assessment of allostatic overload may help to demarcate important differences in patients who otherwise seem deceptively similar because they share the same medical diagnosis, as it was found to be the case in cardiovascular diseases [242-244], particularly congestive heart failure [248], atrial fibrillation [246] and hypertension [249]. Allostatic load acknowledges the burden of different phases of medical disorders. Examples are provided by the post-hospital syndrome, a period of enhanced vulnerability to disease and to adverse events [305]; difficulties related to the process of recovery or rehabilitation [306]; and the cumulative long-standing chronic disease impairment [307]. In general, psychological distress was reported in subjects displaying allostatic 
overload [276-278], which could also be linked to the onset and course of psychiatric disorders [297, 308, 309].

General population studies indicate that allostatic load is increased by low socioeconomic status, living in impoverished neighborhoods, low educational attainment, ethnicity and racial discrimination $[39,93]$. Further, most of the studies indicate a relationship between high levels of allostatic load and work-related stress (including caregiving) with the ensuing risk of burnout syndrome [151, 153, 154]. In this regard, allostatic overload has been used as a conceptual framework for understanding the physical and psychological state of medical health workers facing the COVID-19 pandemic [310, 311]. In older adults, allostatic load was found to be associated with a decline in cognitive and physical functioning, and with frailty, as a multidimensional loss of individual resources [128-132]. Adverse experiences in childhood, including child abuse and maltreatment, were found to predict high levels of allostatic load later in life $[15,312]$. Altogether, individual psychological well-being and coping styles may modulate the association between socio-demographic factors and allostatic load [87], and higher psychosocial resources were linked to lower allostatic load [40, 194]. Environmental factors, such as work and living conditions, play an important role in determining allostatic load $[125,149,162]$, but their modification is often not taken into account. Work conditions are modifiable factors to be targeted by specific interventions [313]. Work reorganization and stress management in employees may reverse allostatic overload and stimulate physiological regeneration processes and recuperation [313]. Inclusion of allostatic load in the clinical assessment allows to view illness within the interaction between the individual and the surrounding environment.

Allostatic load was associated with health-damaging lifestyle habits, such as lack of physical activity, unhealthy diet and poor sleep, in several investigations [52, 228, 229, $233,239]$. The metabolic syndrome, which may be frequently associated with allostatic load [17], is an important example of the devastating effects of harmful lifestyles and of the need to prevent its occurrence as early as possible in life [314]. Individuals may try to counteract manifestations of allostatic overload by the use of medications (e.g., sleeping pills). However, the adverse iatrogenic effects [315] may cause a state of "pharmacological allostatic load" [27] and medications do not entail solution to problems they are used for. Promoting lifestyle modifications and pursuit of psychological well-being, whose importance is increasingly recognized in clinical medicine [316] and psychiatry [317], may provide more enduring effects. Psychotherapeutic strategies aimed at improving coping with stressful situations [304, 318-320] may also be of value. The clinical diagnosis of allostatic overload may be helpful in a comprehensive approach that seeks to understand how the interactions among genetics, mind, body, behavior and the environment affect both the risk of disease and the response to treatment [321]. However, we still lack studies that employ both clinimetric criteria and biological markers. Such investigations would shed some light on the correspondence between clinical and biological parameters, and provide a determination of the state of allostatic overload better than either criteria used alone. In this context, consideration of components that may buffer the impact of stress may be important [313]. In clinimetric terms, this translates into consideration of psychological well-being and euthymia [317, 322]. McEwen [314] has emphasized how coping with daily life challenges is continuously shaping both brain circuitry and systemic physiology, which, in turn, determine lifestyle choices in terms of protective or damaging health behaviors. Such adaptive changes may trigger epigenetic mechanisms $[314,323]$ that modulate physiological and psychological sensitivity and are relevant for regenerative processes [313]. Consideration of the impact of allostatic load on health also calls for a multidisciplinary organization of health care to overcome the artificial boundaries among medical specialties, based mostly on organ systems (e.g., cardiology, endocrinology) that appear more and more inadequate in dealing with symptoms and problems which cut across organ system subdivisions $[303,324,325]$.

\section{Acknowledgments}

We are grateful to Emanuela Offidani, $\mathrm{PhD}$, for helpful suggestions.

\section{Conflict of Interest Statement}

The authors have no conflicts of interest to declare.

\section{Funding Sources}

None.

\section{Author Contributions}

All authors conceived the project. J. Guidi and M. Lucente performed the searches and collected the data. All authors analyzed the data, drafted and revised the paper.
18

Psychother Psychosom 2021;90:11-27 DOI: $10.1159 / 000510696$
Guidi/Lucente/Sonino/Fava 


\section{References}

1 McEwen BS, Stellar E. Stress and the individual. Mechanisms leading to disease. Arch Intern Med. 1993 Sep;153(18):2093-101.

2 Sterling P, Eyer J. Allostasis: a new paradigm to explain arousal pathology. In: Fisher S, Reason J, editors. Handbook of life stress, cognition and health. New York: John Wiley; 1988. pp. 629-49.

3 McEwen BS, Wingfield JC. The concept of allostasis in biology and biomedicine. Horm Behav. 2003 Jan;43(1):2-15.

4 McEwen BS. Stress, adaptation, and disease. Allostasis and allostatic load. Ann N Y Acad Sci. 1998 May;840(1):33-44.

5 McEwen BS. Physiology and neurobiology of stress and adaptation: central role of the brain. Physiol Rev. 2007 Jul;87(3):873-904.

6 Fava GA, McEwen BS, Guidi J, Gostoli S, Offidani E, Sonino N. Clinical characterization of allostatic overload. Psychoneuroendocrinology. 2019 Oct;108:94-101.

7 McEwen BS, Wingfield JC. What is in a name? Integrating homeostasis, allostasis and stress. Horm Behav. 2010 Feb;57(2):105-11.

8 McEwen BS. Protective and damaging effects of stress mediators. N Engl J Med. 1998 Jan; 338(3):171-9.

9 McEwen BS. Central effects of stress hormones in health and disease: understanding the protective and damaging effects of stress and stress mediators. Eur J Pharmacol. 2008 Apr;583(2-3):174-85.

10 Chrousos GP. Stress and disorders of the stress system. Nat Rev Endocrinol. 2009 Jul; 5(7):374-81.

11 McEwen BS, Bowles NP, Gray JD, Hill MN, Hunter RG, Karatsoreos IN, et al. Mechanisms of stress in the brain. Nat Neurosci. 2015 Oct;18(10):1353-63.

12 Gray JD, Kogan JF, Marrocco J, McEwen BS. Genomic and epigenomic mechanisms of glucocorticoids in the brain. Nat Rev Endocrinol. 2017 Nov;13(11):661-73.

13 Dhabhar F, McEwen BS. Bi-directional effects of stress on immune function: possible explanations for salubrious as well as harmful effects. In: Ader R, editor. Psychoneuroimmunology. Volume II. Burlington (Ma): Academic Press; 2007. pp. 723-60.

14 McEwen BS. Biomarkers for assessing population and individual health and disease related to stress and adaptation. Metabolism. 2015 Mar;64(3 Suppl 1):S2-10.

15 Agorastos A, Pervanidou P, Chrousos GP, Baker DG. Developmental Trajectories of Early Life Stress and Trauma: A Narrative Review on Neurobiological Aspects beyond Stress System Dysregulation. Front Psychiatry. 2019 Mar; 10:118.

16 Seeman TE, Singer BH, Rowe JW, Horwitz RI, McEwen BS. Price of adaptation-allostatic load and its health consequences. MacArthur studies of successful aging. Arch Intern Med. 1997 Oct;157(19):2259-68.
17 Seeman TE, McEwen BS, Rowe JW, Singer $\mathrm{BH}$. Allostatic load as a marker of cumulative biological risk: MacArthur studies of successful aging. Proc Natl Acad Sci USA. 2001 Apr; 98(8):4770-5.

18 Gruenewald TL, Seeman TE, Ryff CD, Karlamangla AS, Singer BH. Combinations of biomarkers predictive of later life mortality. Proc Natl Acad Sci USA. 2006 Sep;103(38):1415863.

19 Ryff CD, Dienberg Love G, Urry HL, Muller D, Rosenkranz MA, Friedman EM, et al. Psychological well-being and ill-being: do they have distinct or mirrored biological correlates? Psychother Psychosom. 2006;75(2):85-95.

20 Romero LM, Dickens MJ, Cyr NE. The Reactive Scope Model - a new model integrating homeostasis, allostasis, and stress. Horm Behav. 2009 Mar;55(3):375-89.

21 Shonkoff JP, Boyce WT, McEwen BS. Neuroscience, molecular biology, and the childhood roots of health disparities: building a new framework for health promotion and disease prevention. JAMA. 2009 Jun;301(21):2252-9.

22 Buckwalter JG, Castellani B, McEwen B, Karlamangla AS, Rizzo AA, John B, et al. Allostatic load as a complex clinical construct: a case-based computational modeling approach. Complexity. 2016 Sep-Oct;21(S1 Suppl 1):291-306.

23 Wiley JF, Gruenewald TL, Karlamangla AS, Seeman TE. Modeling multisystem physiological dysregulation. Psychosom Med. 2016 Apr;78(3):290-301.

24 Robertson T, Beveridge G, Bromley C. Allostatic load as a predictor of all-cause and cause-specific mortality in the general population: Evidence from the Scottish Health Survey. PLoS One. 2017 Aug;12(8):e0183297.

25 Mocayar Marón FJ, Ferder L, Saraví FD, Manucha W. Hypertension linked to allostatic load: from psychosocial stress to inflammation and mitochondrial dysfunction. Stress. 2019 Mar;22(2):169-81.

26 McEwen BS, Seeman T. Protective and damaging effects of mediators of stress. Elaborating and testing the concepts of allostasis and allostatic load. Ann N Y Acad Sci. 1999; 896(1):30-47.

27 Juster RP, Bizik G, Picard M, Arsenault-Lapierre G, Sindi S, Trepanier L, et al. A transdisciplinary perspective of chronic stress in relation to psychopathology throughout life span development. Dev Psychopathol. 2011 Aug;23(3):725-76.

28 Juster RP, McEwen BS, Lupien SJ. Allostatic load biomarkers of chronic stress and impact on health and cognition. Neurosci Biobehav Rev. 2010 Sep;35(1):2-16.

29 Beckie TM. A systematic review of allostatic load, health, and health disparities. Biol Res Nurs. 2012 Oct;14(4):311-46.
30 Mauss D, Li J, Schmidt B, Angerer P, Jarczok MN. Measuring allostatic load in the workforce: a systematic review. Ind Health. 2015; 53(1):5-20.

31 Edes AN, Crews DE. Allostatic load and biological anthropology. Am J Phys Anthropol. 2017 Jan;162(S63 Suppl 63):44-70.

32 Feinstein AR. Clinimetrics. New Haven (CT): Yale University Press; 1987. https://doi.org/ 10.2307/j.ctt1xp3vbc.

33 Fava GA, Tomba E, Sonino N. Clinimetrics: the science of clinical measurements. Int J Clin Pract. 2012 Jan;66(1):11-5.

34 Fava GA, Guidi J, Semprini F, Tomba E, Sonino N. Clinical assessment of allostatic load and clinimetric criteria. Psychother Psychosom. 2010;79(5):280-4.

35 Fava GA, Cosci F, Sonino N. Current psychosomatic practice. Psychother Psychosom. 2017;86(1):13-30.

36 Sonino N, Fava GA. A simple instrument for assessing stress in clinical practice. Postgrad Med J. 1998 Jul;74(873):408-10.

37 Piolanti A, Offidani E, Guidi J, Gostoli S, Fava GA, Sonino N. Use of the Psychosocial Index: a sensitive tool in research and practice. Psychother Psychosom. 2016;85(6):337-45.

38 American Psychiatric Association. Diagnostic and Statistical Manual of Mental Disorders. 5th ed. Arlington (VA): American Psychiatric Association; 2013.

39 Johnson SC, Cavallaro FL, Leon DA. A systematic review of allostatic load in relation to socioeconomic position: poor fidelity and major inconsistencies in biomarkers employed. Soc Sci Med. 2017 Nov;192:66-73.

40 Wiley JF, Bei B, Bower JE, Stanton AL. Relationship of psychosocial resources with allostatic load: a systematic review. Psychosom Med. 2017 Apr;79(3):283-92.

41 Moher D, Liberati A, Tetzlaff J, Altman DG; PRISMA Group. Preferred reporting items for systematic reviews and meta-analyses: the PRISMA statement. PLoS Med. 2009 Jul; 6(7):e1000097.

42 Dowd JB, Goldman N. Do biomarkers of stress mediate the relation between socioeconomic status and health? J Epidemiol Community Health. 2006 Jul;60(7):633-9.

43 Crews DE. Composite estimates of physiological stress, age, and diabetes in American Samoans. Am J Phys Anthropol. 2007 Jul; 133(3):1028-34.

44 Yang Y, Kozloski M. Sex differences in age trajectories of physiological dysregulation: inflammation, metabolic syndrome, and allostatic load. J Gerontol A Biol Sci Med Sci. 2011 May;66(5):493-500.

45 Lipowicz A, Szklarska A, Malina RM. Allostatic load and socioeconomic status in Polish adult men. J Biosoc Sci. 2014 Mar;46(2):15567. 
46 Hansen AM, Lund R, Bruunsgaard H, Rod $\mathrm{NH}$, Garde AH, Molbo D, et al. Social gradient in allostatic load among Danish men and women in late midlife. J Aging Health. 2014 Feb;26(1):72-87.

47 Seeman M, Stein Merkin S, Karlamangla A Koretz B, Seeman T. Social status and biological dysregulation: the "status syndrome" and allostatic load. Soc Sci Med. 2014 Oct;118: $143-51$.

48 Gale CR, Booth T, Starr JM, Deary IJ. Intelligence and socioeconomic position in childhood in relation to frailty and cumulative allostatic load in later life: the Lothian Birth Cohort 1936. J Epidemiol Community Health. 2016 Jun;70(6):576-82.

49 Doamekpor LA, Dinwiddie GY. Allostatic load in foreign-born and US-born blacks: evidence from the 2001-2010 National Health and Nutrition Examination Survey. Am I Public Health. 2015 Mar;105(3):591-7.

50 McClure HH, Josh Snodgrass J, Martinez CR Jr, Squires EC, Jiménez RA, Isiordia LE, et al. Stress, place, and allostatic load among Mexican immigrant farmworkers in Oregon. J Immigr Minor Health. 2015 Oct;17(5):1518-25.

51 Rote S. Marital disruption and allostatic load in late life. J Aging Health. 2017 Jun;29(4): 688-707.

52 Kusano Y, Crews DE, Iwamoto A, Sone Y, Aoyagi K, Maeda T, et al. Allostatic load differs by sex and diet, but not age in older Japanese from the Goto Islands. Ann Hum Biol. 2016;43(1):34-41.

53 Robertson T, Watts E. The importance of age, sex and place in understanding socioeconomic inequalities in allostatic load: Evidence from the Scottish Health Survey (2008-2011). BMC Public Health. 2016 Feb; 16(1):126.

54 Chyu L, Upchurch DM. A longitudinal analysis of allostatic load among a multi-ethnic sample of midlife women: findings from the Study of Women's Health Across the Nation. Womens Health Issues. 2018 May - Jun;28(3): 258-66.

55 Tampubolon G, Maharani A. Trajectories of allostatic load among older Americans and Britons: longitudinal cohort studies. BMC Geriatr. 2018 Oct;18(1):255.

56 Mao F, Astell-Burt T, Feng X, Liu Y, Dong J, Liu $\mathrm{S}$, et al. Social and spatial inequalities in allostatic load among adults in China: a multilevel longitudinal study. BMJ Open. 2019 Nov;9(11):e031366.

57 McCrory C, Fiorito G, Ni Cheallaigh C, Polidoro S, Karisola P, Alenius H, et al. How does socio-economic position (SEP) get biologically embedded? A comparison of allostatic load and the epigenetic clock(s). Psychoneuroendocrinology. 2019 Jun;104:64-73.

58 Thomson EM, Kalayci H, Walker M. Cumulative toll of exposure to stressors in Canadians: an allostatic load profile. Health Rep. 2019 Jun;30(6):14-21.
59 Gustafsson PE, Janlert U, Theorell T, Westerlund $\mathrm{H}$, Hammarström A. Socioeconomic status over the life course and allostatic load in adulthood: results from the Northern Swedish Cohort. J Epidemiol Community Health. 2011 Nov;65(11):986-92.

60 Hawkley LC, Lavelle LA, Berntson GG, Cacioppo JT. Mediators of the relationship between socioeconomic status and allostatic load in the Chicago Health, Aging, and Social Relations Study (CHASRS). Psychophysiology. 2011 Aug;48(8):1134-45.

61 Hickson DA, Diez Roux AV, Gebreab SY, Wyatt SB, Dubbert PM, Sarpong DF, et al. Social patterning of cumulative biological risk by education and income among African Americans. Am J Public Health. 2012 Jul; 102(7):1362-9.

62 Gruenewald TL, Karlamangla AS, Hu P, Stein-Merkin S, Crandall C, Koretz B, et al. History of socioeconomic disadvantage and allostatic load in later life. Soc Sci Med. 2012 Jan;74(1):75-83.

63 Seeman TE, Gruenewald TL, Cohen S, Williams DR, Matthews KA. Social relationships and their biological correlates: Coronary Artery Risk Development in Young Adults (CARDIA) study. Psychoneuroendocrinology. 2014 May;43:126-38.

64 Friedman EM, Karlamangla AS, Gruenewald TL, Koretz B, Seeman TE. Early life adversity and adult biological risk profiles. Psychosom Med. 2015 Feb-Mar;77(2):176-85.

65 Upchurch DM, Stein J, Greendale GA, Chyu L, Tseng $\mathrm{CH}$, Huang $\mathrm{MH}$, et al. A Longitudinal investigation of race, socioeconomic status, and psychosocial mediators of allostatic load in midlife women: findings from the Study of Women's Health Across the Nation. Psychosom Med. 2015 May;77(4):402-12.

66 Lipowicz A, Szklarska A, Mitas AW. Biological costs of economic transition: stress levels during the transition from communism to capitalism in Poland. Econ Hum Biol. 2016 May;21:90-9.

67 Christensen DS, Flensborg-Madsen T, Garde E, Hansen AM, Pedersen JM, Mortensen EL. Parental socioeconomic position and midlife allostatic load: a study of potential mediators. BMC Public Health. 2018 Aug;18(1):1029.

68 Rodriguez JM, Karlamangla AS, Gruenewald TL, Miller-Martinez D, Merkin SS, Seeman TE. Social stratification and allostatic load: shapes of health differences in the MIDUS study in the United States. J Biosoc Sci. 2019 Sep;51(5):627-44.

69 Weinstein M, Goldman N, Hedley A, YuHsuan L, Seeman T. Social linkages to biological markers of health among the elderly. J Biosoc Sci. 2003 Jul;35(3):433-53.

70 Robertson T, Popham F, Benzeval M. Socioeconomic position across the lifecourse \& allostatic load: data from the West of Scotland Twenty-07 cohort study. BMC Public Health. 2014 Feb;14(1):184.
$71 \mathrm{Xu} \mathrm{H}$. Multilevel socioeconomic differentials in allostatic load among Chinese adults. Health Place. 2018 Sep;53:182-92.

72 Präg P, Richards L. Intergenerational social mobility and allostatic load in Great Britain. J Epidemiol Community Health. 2019 Feb; 73(2):100-5.

73 Seeman T, Merkin SS, Crimmins E, Koretz B, Charette S, Karlamangla A. Education, income and ethnic differences in cumulative biological risk profiles in a national sample of US adults: NHANES III (1988-1994). Soc Sci Med. 2008 Jan;66(1):72-87.

74 Daly M, Boyce C, Wood A. A social rank explanation of how money influences health. Health Psychol. 2015 Mar;34(3):222-30.

75 Evans GW. Childhood poverty and adult psychological well-being. Proc Natl Acad Sci USA. 2016 Dec;113(52):14949-52.

76 Hounkpatin HO, Wood AM, Dunn G. Does income relate to health due to psychosocial or material factors? Consistent support for the psychosocial hypothesis requires operationalization with income rank not the Yitzhaki Index. Soc Sci Med. 2016 Feb;150:76-84.

77 Buschmann RN, Prochaska JD, Cutchin MP, Peek MK. Stress and health behaviors as potential mediators of the relationship between neighborhood quality and allostatic load. Ann Epidemiol. 2018 Jun;28(6):356-61.

78 Cunningham-Myrie CA, Mabile E, Govia I, Younger NO, Tulloch-Reid MK, McFarlane $S$, et al. Neighbourhood characteristics and cumulative biological risk: evidence from the Jamaica Health and Lifestyle Survey 2008: a cross-sectional study. BMJ Open. 2018 Dec; 8(12): 021952

79 Bird CE, Seeman T, Escarce JJ, Basurto-Dávila R, Finch BK, Dubowitz T, et al. Neighbourhood socioeconomic status and biological 'wear and tear' in a nationally representative sample of US adults. J Epidemiol Community Health. 2010 Oct;64(10):860-5.

80 Schulz AJ, Mentz G, Lachance L, Johnson J, Gaines C, Israel BA. Associations between socioeconomic status and allostatic load: effects of neighborhood poverty and tests of mediating pathways. Am J Public Health. 2012 Sep; 102(9):1706-14.

81 Wallace M, Harville E, Theall K, Webber L, Chen W, Berenson G. Neighborhood poverty, allostatic load, and birth outcomes in African American and white women: findings from the Bogalusa Heart Study. Health Place. 2013 Nov;24:260-6.

82 Jiménez MP, Osypuk TL, Arevalo S, Tucker KL, Falcon LM. Neighborhood socioeconomic context and change in allostatic load among older Puerto Ricans: the Boston Puerto Rican health study. Health Place. 2015 May;33:1-8.

83 Robinette JW, Charles ST, Almeida DM, Gruenewald TL. Neighborhood features and physiological risk: an examination of allostatic load. Health Place. 2016 Sep;41:110-8. 
84 Prior L, Manley D, Jones K. Stressed out? An investigation of whether allostatic load mediates associations between neighbourhood deprivation and health. Health Place. 2018 Jul; 52:25-33.

85 Ribeiro AI, Fraga S, Kelly-Irving M, Delpierre C, Stringhini S, Kivimaki M, et al. Neighbourhood socioeconomic deprivation and allostatic load: a multi-cohort study. Sci Rep. 2019 Jun;9(1):8790.

86 Bellatorre A, Finch BK, Do DP, Bird CE, Beck AN. Contextual predictors of cumulative biological risk: segregation and allostatic load. Soc Sci Q. 2011 Oct;92(5):1338-62.

87 Chen E, Miller GE, Lachman ME, Gruenewald TL, Seeman TE. Protective factors for adults from low-childhood socioeconomic circumstances: the benefits of shift-and-persist for allostatic load. Psychosom Med. 2012 Feb-Mar;74(2):178-86.

88 Robertson T, Benzeval M, Whitley E, Popham F. The role of material, psychosocial and behavioral factors in mediating the association between socioeconomic position and allostatic load (measured by cardiovascular, metabolic and inflammatory markers). Brain Behav Immun. 2015 Mar;45:41-9.

89 Christensen DS, Flensborg-Madsen T, Garde E, Hansen AM, Masters Pedersen J, Mortensen EL. Early life predictors of midlife allostatic load: A prospective cohort study. PLoS One. 2018 Aug;13(8):e0202395.

90 Hamdi NR, South SC, Krueger RF. Does education lower allostatic load? A co-twin control study. Brain Behav Immun. 2016 Aug;56: 221-9.

91 Ding X, Barban N, Mills MC. Educational attainment and allostatic load in later life: evidence using genetic markers. Prev Med. 2019 Dec; 129:105866.

92 Tan M, Mamun A, Kitzman H, Dodgen L. Longitudinal changes in allostatic load during a randomized church-based, lifestyle intervention in African American women. Ethn Dis. 2019 Apr;29(2):297-308.

93 Howard JT, Sparks PJ. The role of education in explaining racial/ethnic allostatic load differentials in the United States. Biodemogr Soc Biol. 2015;61(1):18-39.

94 Sims J, Coley RL. Variations in links between educational success and health: implications for enduring health disparities. Cultur Divers Ethnic Minor Psychol. 2019 Jan;25(1):32-43.

95 Geronimus AT, Hicken M, Keene D, Bound J. "Weathering" and age patterns of allostatic load scores among blacks and whites in the United States. Am J Public Health. 2006 May; 96(5):826-33.

96 Chyu L, Upchurch DM. Racial and ethnic patterns of allostatic load among adult women in the United States: findings from the National Health and Nutrition Examination Survey 1999-2004. J Womens Health (Larchmt). 2011 Apr;20(4):575-83.
97 Cobb RJ, Thomas CS, Laster Pirtle WN, Darity WA Jr. Self-identified race, socially assigned skin tone, and adult physiological dysregulation: assessing multiple dimensions of "race" in health disparities research. SSM Popul Health. 2016 Aug;2:595-602.

98 Dormire SL. Life stress, race, and abnormal glucose metabolism in postmenopausal women. J Am Geriatr Soc. 2016 Sep;64(9):e46-8.

99 Thomas Tobin CS, Robinson MN, Stanifer K. Does marriage matter? Racial differences in allostatic load among women. Prev Med Rep. 2019 Jul;15:100948.

100 Kaestner R, Pearson JA, Keene D, Geronimus AT. Stress, allostatic load and health of Mexican immigrants. Soc Sci Q. 2009 Dec; 90(5):1089-111.

101 Bingham BA, Duong MT, Ricks M, Mabundo LS, Baker RL Jr, Utumatwishima JN, et al. The association between stress measured by allostatic load score and physiologic dysregulation in African immigrants: the Africans in America study. Front Public Health. 2016 Nov;4:265.

102 Salazar CR, Strizich G, Seeman TE, Isasi CR, Gallo LC, Avilés-Santa ML, et al. Nativity differences in allostatic load by age, sex, and Hispanic background from the Hispanic Community Health Study/Study of Latinos. SSM Popul Health. 2016 Dec;2:416-24.

103 Allen AM, Thomas MD, Michaels EK, Reeves AN, Okoye U, Price MM, et al. Racial discrimination, educational attainment, and biological dysregulation among midlife African American women. Psychoneuroendocrinology. 2019 Jan;99:225-35.

104 Thomas MD, Michaels EK, Reeves AN, Okoye U, Price MM, Hasson RE, et al. Differential associations between everyday versus institution-specific racial discrimination, self-reported health, and allostatic load among black women: implications for clinical assessment and epidemiologic studies. Ann Epidemiol. 2019 Jul;35:20-28.e3.

105 O'Campo P, Schetter CD, Guardino CM, Vance MR, Hobel CJ, Ramey SL, et al. Explaining racial and ethnic inequalities in postpartum allostatic load: results from a multisite study of low to middle income woment. SSM Popul Health. 2016 Dec;2:850-8.

106 Schwartz JA. Long-term physical health consequences of perceived inequality: results from a twin comparison design. Soc Sci Med. 2017 Aug;187:184-92.

107 Gustafsson PE, Janlert U, Theorell T, Westerlund $\mathrm{H}, \mathrm{Hammarström}$ A. Social and material adversity from adolescence to adulthood and allostatic load in middle-aged women and men: results from the Northern Swedish Cohort. Ann Behav Med. 2012 Feb; 43(1):117-28.

108 Westerlund H, Gustafsson PE, Theorell T, Janlert U, Hammarström A. Social adversity in adolescence increases the physiological vulnerability to job strain in adulthood: a prospective population-based study. PLoS One. 2012;7(4):e35967.
109 Arévalo SP, Tucker KL, Falcón LM. Life events trajectories, allostatic load, and the moderating role of age at arrival from Puerto Rico to the US mainland. Soc Sci Med. 2014 Nov; 120:301-10.

110 Ong AD, Williams DR, Nwizu U, Gruenewald TL. Everyday unfair treatment and multisystem biological dysregulation in African American adults. Cultur Divers Ethnic Minor Psychol. 2017 Jan;23(1):27-35.

111 Zilioli S, Imami L, Ong AD, Lumley MA, Gruenewald T. Discrimination and anger control as pathways linking socioeconomic disadvantage to allostatic load in midlife. J Psychosom Res. 2017 Dec;103:83-90.

112 Cuevas AG, Wang K, Williams DR, Mattei J, Tucker KL, Falcon LM. The association between perceived discrimination and allostatic load in the Boston Puerto Rican Health Study. Psychosom Med. 2019 Sep;81(7): 659-67.

113 Currie CL, Copeland JL, Metz GA. Childhood racial discrimination and adult allostatic load: the role of Indigenous cultural continuity in allostatic resiliency. Soc Sci Med. 2019 Nov;241:112564.

114 Rosemberg MS, Li Y, McConnell DS, McCullagh MC, Seng JS. Stressors, allostatic load, and health outcomes among women hotel housekeepers: A pilot study. J Occup Environ Hyg. 2019 Mar;16(3):206-17.

115 D'Alonzo KT, Munet-Vilaro F, Carmody DP, Guarnaccia PJ, Linn AM, Garsman L. Acculturation stress and allostatic load among Mexican immigrant women. Rev Lat Am Enfermagem. 2019 Apr;27:e3135.

116 D’Alonzo KT, Johnson S, Fanfan D. A biobehavioral approach to understanding obesity and the development of obesogenic illnesses among Latino immigrants in the United States. Biol Res Nurs. 2012 Oct;14(4):36474.

117 Vadiveloo M, Mattei J. Perceived weight discrimination and 10-year risk of allostatic load among US adults. Ann Behav Med. 2017 Feb;51(1):94-104.

118 Juster RP, Lupien S. A sex- and gender-based analysis of allostatic load and physical complaints. Gend Med. 2012 Dec;9(6):511-23.

119 Juster RP, Ouellet É, Lefebvre-Louis JP, Sindi S, Johnson PJ, Smith NG, et al. Retrospective coping strategies during sexual identity formation and current biopsychosocial stress. Anxiety Stress Coping. 2016;29(2): 119-38.

120 Juster RP, Almeida D, Cardoso C, Raymond C, Johnson PJ, Pfaus JG, et al. Gonads and strife: sex hormones vary according to sexual orientation for women and stress indices for both sexes. Psychoneuroendocrinology. 2016 Oct; 72:119-30.

121 Juster RP, Pruessner JC, Desrochers AB, Bourdon O, Durand N, Wan N, et al. Sex and gender roles in relation to mental health and allostatic load. Psychosom Med. 2016 Sep; 78(7):788-804 
122 Mays VM, Juster RP, Williamson TJ, Seeman TE, Cochran SD. Chronic physiologic effects of stress among lesbian, gay, and bisexual adults: Results from the National Health and Nutrition Examination Survey. Psychosom Med. 2018 Jul/Aug;80(6):55163.

123 Hill TD, Rote SM, Ellison CG. Religious participation and biological functioning in Mexico. J Aging Health. 2017 Sep;29(6): 951-72.

124 Maselko J, Kubzansky L, Kawachi I, Seeman T, Berkman L. Religious service attendance and allostatic load among high-functioning elderly. Psychosom Med. 2007 Jun;69(5): 464-72.

125 Morales-Jinez A, Gallegos Cabriales EC, D'Alonzo KT, Ugarte-Esquivel A, LopezRincon FJ, Salazar-Gonzalez BC. Social factors contributing to the development of allostatic load in older adults: a correlationalpredictive study. Aquichan. 2018 Jul-Sep; 18(3):298-310.

126 Suh H, Hill TD, Koenig HG. Religious attendance and biological risk: a national longitudinal study of older adults. J Relig Health. 2019 Aug;58(4):1188-202.

127 Bruce MA, Martins D, Duru K, Beech BM, Sims M, Harawa N, et al. Church attendance, allostatic load and mortality in middle aged adults. PLoS One. 2017 May;12(5):e0177618.

128 Gruenewald TL, Seeman TE, Karlamangla AS, Sarkisian CA. Allostatic load and frailty in older adults. J Am Geriatr Soc. 2009 Sep; 57(9):1525-31.

129 Fried LP, Xue QL, Cappola AR, Ferrucci L, Chaves P, Varadhan R, et al. Nonlinear multisystem physiological dysregulation associated with frailty in older women: implications for etiology and treatment. J Gerontol A Biol Sci Med Sci. 2009 Oct;64(10):104957.

130 Ding YY, Kuha J, Murphy M. Multidimensional predictors of physical frailty in older people: identifying how and for whom they exert their effects. Biogerontology. 2017 Apr;18(2):237-52.

131 Szanton SL, Allen JK, Seplaki CL, BandeenRoche K, Fried LP. Allostatic load and frailty in the women's health and aging studies. Biol Res Nurs. 2009 Jan;10(3):248-56.

132 Karlamangla AS, Singer BH, McEwen BS, Rowe JW, Seeman TE. Allostatic load as a predictor of functional decline. MacArthur studies of successful aging. J Clin Epidemiol. 2002 Jul;55(7):696-710.

133 Crimmins EM, Johnston M, Hayward M, Seeman T. Age differences in allostatic load: an index of physiological dysregulation. Exp Gerontol. 2003 Jul;38(7):731-4.

134 Read S, Grundy E. Allostatic load and health in the older population of England: a crossed-lagged analysis. Psychosom Med. 2014 Sep;76(7):490-6.
135 Crook Z, Booth T, Cox SR, Corley J, Dykiert $\mathrm{D}$, Redmond P, et al. Apolipoprotein E genotype does not moderate the associations of depressive symptoms, neuroticism and allostatic load with cognitive ability and cognitive aging in the Lothian Birth Cohort 1936. PLoS One. 2018 Feb;13(2):e0192604.

136 Ritchie SJ, Tucker-Drob EM, Cox SR, Dickie DA, Del C Valdés Hernández M, Corley J, et al. Risk and protective factors for structural brain ageing in the eighth decade of life. Brain Struct Funct. 2017 Nov;222(8):347790.

137 Cole JH, Ritchie SJ, Bastin ME, Valdés Hernández MC, Muñoz Maniega S, Royle N, et al. Brain age predicts mortality. Mol Psychiatry. 2018 May;23(5):1385-92.

138 Booth T, Royle NA, Corley J, Gow AJ, Valdés Hernández MC, Muñoz Maniega S, et al. Association of allostatic load with brain structure and cognitive ability in later life. Neurobiol Aging. 2015 Mar;36(3):1390-9.

139 Wikby A, Ferguson F, Forsey R, Thompson J, Strindhall J, Löfgren S, et al. An immune risk phenotype, cognitive impairment, and survival in very late life: impact of allostatic load in Swedish octogenarian and nonagenarian humans. J Gerontol A Biol Sci Med Sci. 2005 May;60(5):556-65.

140 Rigney T. Allostatic load and delirium in the hospitalized older adult. Nurs Res. 2010 SepOct;59(5):322-30.

141 Seeman TE, Crimmins E, Huang MH, Singer B, Bucur A, Gruenewald T, et al. Cumulative biological risk and socio-economic differences in mortality: MacArthur studies of successful aging. Soc Sci Med. 2004 May; 58(10):1985-97.

142 Karlamangla AS, Singer BH, Seeman TE. Reduction in allostatic load in older adults is associated with lower all-cause mortality risk: MacArthur studies of successful aging. Psychosom Med. 2006 May-Jun;68(3):5007.

143 Stephan Y, Sutin AR, Luchetti M, Terracciano A. Allostatic load and personality: a 4-year longitudinal study. Psychosom Med. 2016 Apr;78(3):302-10.

144 Morales-Jinez A, López-Rincón FJ, UgarteEsquivel A, Andrade-Valles I, RodríguezMejía LE, Hernández-Torres JL. Allostatic load and canine companionship: a comparative study using biomarkers in older adults. Rev Lat Am Enfermagem. 2018 Nov; 26(0):e3071.

145 Zheng DD, Christ SL, Lam BL, Tannenbaum SL, Bokman CL, Arheart KL, et al. Visual acuity and increased mortality: the role of allostatic load and functional status. Invest Ophthalmol Vis Sci. 2014 Jul;55(8):514450.

146 Bellingrath S, Weigl T, Kudielka BM. Chronic work stress and exhaustion is associated with higher allostastic load in female school teachers. Stress. 2009 Jan;12(1):37-48.
147 de Castro AB, Voss JG, Ruppin A, Dominguez CF, Seixas NS. Stressors among Latino day laborers. A pilot study examining allostatic load. AAOHN J. 2010 May;58(5):18596.

148 Mauss D, Jarczok MN, Fischer JE. A streamlined approach for assessing the Allostatic Load Index in industrial employees. Stress. 2015;18(4):475-83.

149 Mauss D, Jarczok MN, Fischer JE. The streamlined Allostatic Load Index: a replication of study results. Stress. 2016 Nov; 19(6): 553-8.

150 Sun J, Wang S, Zhang JQ, Li W. Assessing the cumulative effects of stress: the association between job stress and allostatic load in a large sample of Chinese employees. Work Stress. 2007 Nov;21(4):333-47.

151 Dich N, Lange T, Head J, Rod NH. Work stress, caregiving, and allostatic load: prospective results from the Whitehall II cohort study. Psychosom Med. 2015 Jun;77(5): 539-47.

152 Chandola T, Zhang N. Re-employment, job quality, health and allostatic load biomarkers: prospective evidence from the UK Household Longitudinal Study. Int J Epidemiol. 2018 Feb;47(1):47-57.

153 Juster RP, Sindi S, Marin MF, Perna A, Hashemi A, Pruessner JC, et al. A clinical allostatic load index is associated with burnout symptoms and hypocortisolemic profiles in healthy workers. Psychoneuroendocrinology. 2011 Jul;36(6):797-805.

154 Hintsa T, Elovainio M, Jokela M, Ahola K, Virtanen M, Pirkola S. Is there an independent association between burnout and increased allostatic load? Testing the contribution of psychological distress and depression. J Health Psychol. 2016 Aug;21(8): 1576-86.

155 Langelaan S, Bakker AB, Schaufeli WB, van Rhenen W, van Doornen LJ. Is burnout related to allostatic load? Int J Behav Med. 2007;14(4):213-21.

156 Limm H, Angerer P, Heinmueller M, Marten-Mittag B, Nater UM, Guendel H. Selfperceived stress reactivity is an indicator of psychosocial impairment at the workplace. BMC Public Health. 2010 May;10(1):252.

157 Näswall K, Lindfors P, Sverke M. Job insecurity as a predictor of physiological indicators of health in healthy working women: an extension of previous research. Stress Health. 2012 Aug;28(3):255-63.

158 Juster RP, Moskowitz DS, Lavoie J, D’Antono B. Sex-specific interaction effects of age, occupational status, and workplace stress on psychiatric symptoms and allostatic load among healthy Montreal workers. Stress. 2013 Nov; 16(6):616-29.

159 Viljoen M, Claassen N. Allostatic load and heart rate variability as health risk indicators. Afr Health Sci. 2017 Jun;17(2):428-35. 
160 von Thiele U, Lindfors P, Lundberg U. Selfrated recovery from work stress and allostatic load in women. J Psychosom Res. 2006 Aug;61(2):237-42.

161 Schnorpfeil P, Noll A, Schulze R, Ehlert U, Frey K, Fischer JE. Allostatic load and work conditions. Soc Sci Med. 2003 Aug;57(4): 647-56.

162 Carlsson RH, Hansen AM, Nielsen ML, Blønd M, Netterstrøm B. Changes in Allostatic Load during workplace reorganization. J Psychosom Res. 2017 Dec;103:34-41.

163 Patel PC, Wolfe MT, Williams TA. Self-employment and allostatic load. J Bus Venturing. 2019 Jul;34(4):731-51.

164 Coronado JI, Chandola T, Steptoe A. Allostatic load and effort-reward imbalance: associations over the working-career. Int J Environ Res Public Health. 2018 Jan;15(2):e191.

165 Dich N, Doan SN, Kivimäki M, Kumari M, Rod NH. A non-linear association between self-reported negative emotional response to stress and subsequent allostatic load: prospective results from the Whitehall II cohort study. Psychoneuroendocrinology. 2014 Nov;49:54-61.

166 Egorov AI, Griffin SM, Converse RR, Styles JN, Sams EA, Wilson A, et al. Vegetated land cover near residence is associated with reduced allostatic load and improved biomarkers of neuroendocrine, metabolic and immune functions. Environ Res. 2017 Oct; 158:508-21.

167 Egorov AI, Converse R, Griffin SM, Styles J, Klein E, Sams E, et al. Environmental risk factors for Toxoplasma gondii infections and the impact of latent infections on allostatic load in residents of Central North Carolina. BMC Infect Dis. 2018 Aug;18(1):421.

168 Zota AR, Shenassa ED, Morello-Frosch R. Allostatic load amplifies the effect of blood lead levels on elevated blood pressure among middle-aged U.S. adults: a cross-sectional study. Environ Health. 2013 Aug; 12(1):64.

169 Souza-Talarico JN, Suchecki D, Juster RP, Plusquellec P, Barbosa Junior F, Bunscheit $\mathrm{V}$, et al. Lead exposure is related to hypercortisolemic profiles and allostatic load in Brazilian older adults. Environ Res. 2017 Apr; 154:261-8.

170 van Deurzen I, Rod NH, Christensen U, Hansen AM, Lund R, Dich N. Neighborhood perceptions and allostatic load: evidence from Denmark. Health Place. 2016 Jul;40:1-8.

171 Riva M, Plusquellec P, Juster RP, LaouanSidi EA, Abdous B, Lucas M, et al. Household crowding is associated with higher allostatic load among the Inuit. J Epidemiol Community Health. 2014 Apr;68(4):363-9.

172 Mair CA, Cutchin MP, Kristen Peek M. Allostatic load in an environmental riskscape: the role of stressors and gender. Health Place. 2011 Jul;17(4):978-87.
173 Jung CC, Liang HH, Lee HL, Hsu NY, Su HJ. Allostatic load model associated with indoor environmental quality and sick building syndrome among office workers. PLoS One. 2014 Apr;9(4):e95791.

174 Carroll JE, Gruenewald TL, Taylor SE, Janicki-Deverts D, Matthews KA, Seeman TE. Childhood abuse, parental warmth, and adult multisystem biological risk in the Coronary Artery Risk Development in Young Adults study. Proc Natl Acad Sci USA. 2013 Oct;110(42):17149-53.

175 Barboza Solís C, Kelly-Irving M, Fantin R, Darnaudéry M, Torrisani J, Lang T, et al. Adverse childhood experiences and physiological wear-and-tear in midlife: findings from the 1958 British birth cohort. Proc Natl Acad Sci USA. 2015 Feb;112(7):E738-46.

176 Dich N, Hansen AM, Avlund K, Lund R, Mortensen EL, Bruunsgaard H, et al. Early life adversity potentiates the effects of later life stress on cumulative physiological dysregulation. Anxiety Stress Coping. 2015; 28(4):372-90.

177 Tomasdottir MO, Sigurdsson JA, Petursson $\mathrm{H}$, Kirkengen AL, Krokstad S, McEwen B, et al. Self reported childhood difficulties, adult multimorbidity and allostatic load: A crosssectional analysis of the Norwegian HUNT Study. PLoS One. 2015 Jun;10(6):e0130591.

178 Widom CS, Horan J, Brzustowicz L. Childhood maltreatment predicts allostatic load in adulthood. Child Abuse Negl. 2015 Sep; 47:59-69.

179 Berg MT, Simons RL, Barr A, Beach SR, Philibert RA. Childhood/Adolescent stressors and allostatic load in adulthood: support for a calibration model. Soc Sci Med. 2017 Nov; 193:130-9.

180 Wallace M, Felker-Kantor E, Madkour A, Ferguson T, Welsh D, Molina P, et al. Adverse childhood experiences, smoking and alcohol use, and allostatic load among people living with HIV. AIDS Behav. 2020 Jun; 24(6):1653-62.

181 Turner RJ, Thomas CS, Brown TH. Childhood adversity and adult health: evaluating intervening mechanisms. Soc Sci Med. 2016 May;156:114-24.

182 Horan JM, Widom CS. From childhood maltreatment to allostatic load in adulthood: the role of social support. Child Maltreat. 2015 Nov;20(4):229-39.

183 Brody GH, Yu T, Barton AW, Miller GE, Chen E. Youth temperament, harsh parenting, and variation in the oxytocin receptor gene forecast allostatic load during emerging adulthood. Dev Psychopathol. 2017 Aug; 29(3):791-803.

184 Brody GH, Yu T, Chen YF, Kogan SM, Evans GW, Windle M, et al. Supportive family environments, genes that confer sensitivity, and allostatic load among rural African American emerging adults: a prospective analysis. J Fam Psychol. 2013 Feb;27(1):229.
185 Priest JB, Woods SB, Maier CA, Parker EO, Benoit JA, Roush TR. The Biobehavioral Family Model: close relationships and allostatic load. Soc Sci Med. 2015 Oct;142:23240.

186 Priest JB, Roberson PN, Woods SB. In our lives and under our skin: an investigation of specific psychobiological mediators linking family relationships and health using the biobehavioral family model. Fam Process. 2019 Mar;58(1):79-99.

187 Slopen N, Chen Y, Priest N, Albert MA, Williams DR. Emotional and instrumental support during childhood and biological dysregulation in midlife. Prev Med. 2016 Mar; 84:90-6.

188 Westerlund H, Gustafsson PE, Theorell T, Janlert U, Hammarström A. Parental academic involvement in adolescence, academic achievement over the life course and allostatic load in middle age: a prospective population-based cohort study. J Epidemiol Community Health. 2013 Jun;67(6):508-13.

189 Hill-Soderlund AL, Mills-Koonce WR, Propper C, Calkins SD, Granger DA, Moore GA, et al. Parasympathetic and sympathetic responses to the strange situation in infants and mothers from avoidant and securely attached dyads. Dev Psychobiol. 2008 May; 50(4):361-76.

190 Widom CS, Czaja SJ, Kozakowski SS, Chauhan P. Does adult attachment style mediate the relationship between childhood maltreatment and mental and physical health outcomes? Child Abuse Negl. 2018 Feb;76: 533-45.

191 Schenk HM, Jeronimus BF, van der Krieke L, Bos EH, de Jonge P, Rosmalen JG. Associations of positive affect and negative affect with allostatic load: a lifelines cohort study. Psychosom Med. 2018 Feb/Mar;80(2):1606.

192 Zilioli S, Slatcher RB, Ong AD, Gruenewald TL. Purpose in life predicts allostatic load ten years later. J Psychosom Res. 2015 Nov; 79(5):451-7.

193 Seeman T, Glei D, Goldman N, Weinstein $\mathrm{M}$, Singer B, Lin YH. Social relationships and allostatic load in Taiwanese elderly and near elderly. Soc Sci Med. 2004 Dec;59(11): 2245-57.

194 Seeman TE, Singer BH, Ryff CD, Dienberg Love G, Levy-Storms L. Social relationships, gender, and allostatic load across two age cohorts. Psychosom Med. 2002 May-Jun; 64(3):395-406.

195 Glei DA, Goldman N, Chuang YL, Weinstein M. Do chronic stressors lead to physiological dysregulation? Testing the theory of allostatic load. Psychosom Med. 2007 Nov; 69(8):769-76.

196 Brooks KP, Gruenewald T, Karlamangla A, $\mathrm{Hu}$ P, Koretz B, Seeman TE. Social relationships and allostatic load in the MIDUS study. Health Psychol. 2014 Nov;33(11): 1373-81. 
197 Lindfors P, Lundberg O, Lundberg U. Allostatic load and clinical risk as related to sense of coherence in middle-aged women. Psychosom Med. 2006 Sep-Oct;68(5):801-7.

198 Fernandez CA, Loucks EB, Arheart KL, Hickson DA, Kohn R, Buka SL, et al. Evaluating the effects of coping style on allostatic load, by sex: the Jackson Heart study, 20002004. Prev Chronic Dis. 2015 Oct;12:E165.

199 Ellis EM, Prather AA, Grenen EG, Ferrer RA. Direct and indirect associations of cognitive reappraisal and suppression with disease biomarkers. Psychol Health. 2019 Mar; 34(3):336-54.

200 Gutiérrez-Robledo LM, García-Chanes RE, Pérez-Zepeda MU. Allostatic load as a biological substrate to intrinsic capacity: a secondary analysis of CRELES. J Nutr Health Aging. 2019;23(9):788-95.

201 von Känel R, Dimsdale JE, Patterson TL, Grant I. Acute procoagulant stress response as a dynamic measure of allostatic load in Alzheimer caregivers. Ann Behav Med. 2003 Aug;26(1):42-8.

202 Roepke SK, Mausbach BT, Patterson TL, Von Känel R, Ancoli-Israel S, Harmell AL, et al. Effects of Alzheimer caregiving on allostatic load. J Health Psychol. 2011 Jan;16(1): 58-69.

203 Song J, Mailick MR, Ryff CD, Coe CL, Greenberg JS, Hong J. Allostatic load in parents of children with developmental disorders: moderating influence of positive affect. J Health Psychol. 2014 Feb;19(2):262-72.

204 Singer B, Ryff CD. Hierarchies of life histories and associated health risks. Ann N Y Acad Sci. 1999;896(1):96-115.

205 Deuster PA, Kim-Dorner SJ, Remaley AT, Poth M. Allostatic load and health status of African Americans and whites. Am J Health Behav. 2011 Nov;35(6):641-53.

206 Todorova IL, Tucker KL, Jimenez MP, Lincoln AK, Arevalo S, Falcón LM. Determinants of self-rated health and the role of acculturation: implications for health inequalities. Ethn Health. 2013;18(6):563-85.

207 Barboza Solís C, Fantin R, Kelly-Irving M, Delpierre C. Physiological wear-and-tear and later subjective health in mid-life: findings from the 1958 British birth cohort. Psychoneuroendocrinology. 2016 Dec;74:2433.

208 Chiu CJ, Lin YC. Spousal health and older adults' biomarker change over six years: investigation of gender differences. Arch Gerontol Geriatr. 2019 Jul - Aug;83:44-9.

209 Mattei J, Demissie S, Falcon LM, Ordovas JM, Tucker K. Allostatic load is associated with chronic conditions in the Boston Puerto Rican Health Study. Soc Sci Med. 2010 Jun;70(12):1988-96.

210 Hollar D. Cross-sectional changes in patterns of allostatic load among persons with varying disabilities, NHANES: 2001-2010. Disabil Health J. 2013 Jul;6(3):177-87.
211 Slade GD, Sanders AE, By K. Role of allostatic load in sociodemographic patterns of pain prevalence in the U.S. population. J Pain. 2012 Jul;13(7):666-75.

212 Sibille KT, McBeth J, Smith D, Wilkie R. Allostatic load and pain severity in older adults: Results from the English Longitudinal Study of Ageing. Exp Gerontol. $2017 \mathrm{Feb}$; 88:51-8.

213 Borrell LN, Dallo FJ, Nguyen N. Racial/ethnic disparities in all-cause mortality in U.S. adults: the effect of allostatic load. Public Health Rep. 2010 Nov-Dec;125(6):810-6.

214 Duru OK, Harawa NT, Kermah D, Norris KC. Allostatic load burden and racial disparities in mortality. J Natl Med Assoc. 2012 Jan-Feb;104(1-2):89-95.

215 Hwang AC, Peng LN, Wen YW, Tsai YW, Chang LC, Chiou ST, et al. Predicting allcause and cause-specific mortality by static and dynamic measurements of allostatic load: a 10-year population-based cohort study in Taiwan. J Am Med Dir Assoc. 2014 Jul;15(7):490-6.

216 Howard JT, Sparks PJ. The effects of allostatic load on racial/ethnic mortality differences in the United States. Popul Res Policy Rev. 2016 Jan;35(4):421-43.

217 Castagné R, Garès V, Karimi M, ChadeauHyam M, Vineis P, Delpierre C, et al.; Lifepath Consortium. Allostatic load and subsequent all-cause mortality: which biological markers drive the relationship? Findings from a UK birth cohort. Eur J Epidemiol. 2018 May;33(5):441-58.

218 Beydoun HA, Huang S, Beydoun MA, Hossain S, Zonderman AB. Mediating-moderating effect of allostatic load on the association between Dietary Approaches to Stop Hypertension diet and all-cause and cause-specific mortality: 2001-2010 National Health and Nutrition Examination Surveys. Nutrients. 2019 Sep;11(10):e2311.

219 Lekander M, Elofsson S, Neve IM, Hansson LO, Undén AL. Self-rated health is related to levels of circulating cytokines. Psychosom Med. 2004 Jul-Aug;66(4):559-63.

220 Goldman N, Glei DA, Chang MC. The role of clinical risk factors in understanding selfrated health. Ann Epidemiol. 2004 Jan; 14(1):49-57.

221 Hu P, Wagle N, Goldman N, Weinstein M, Seeman TE. The associations between socioeconomic status, allostatic load and measures of health in older Taiwanese persons: taiwan social environment and biomarkers of aging study. J Biosoc Sci. 2007 Jul;39(4): 545-56.

222 Hasson D, Von Thiele Schwarz U, Lindfors P. Self-rated health and allostatic load in women working in two occupational sectors. J Health Psychol. 2009 May; 14(4):56877.

223 Santos-Lozada AR, Howard JT. Using allostatic load to validate self-rated health for racial/ethnic groups in the United States. Biodemogr Soc Biol. 2018 Jan-Mar;64(1):1-14.
224 Ahrens KA, Rossen LM, Simon AE. Relationship between mean leucocyte telomere length and measures of allostatic load in US reproductive-aged women, NHANES 1999_ 2002. Paediatr Perinat Epidemiol. 2016 Jul 30(4):325-35.

225 Frei R, Haile SR, Mutsch M, Rohrmann S. Relationship of serum vitamin D concentrations and allostatic load as a measure of $\mathrm{cu}$ mulative biological risk among the US population: a cross-sectional study. PLoS One. 2015 Oct;10(10):e0139217.

226 Rosenberg N, Park CG, Eldeirawi K. Relationship of serum carotenoid concentrations with allostatic load as a measure of chronic stress among middle-aged adults in the USA. Public Health Nutr. 2015 Feb; 18(2):313-21.

227 Gay JL, Salinas JJ, Buchner DM, Mirza S, Kohl HW 3rd, Fisher-Hoch SP, et al. Meeting physical activity guidelines is associated with lower allostatic load and inflammation in Mexican Americans. J Immigr Minor Health. 2015 Apr;17(2):574-81.

228 Petrovic D, Pivin E, Ponte B, Dhayat N, Pruijm M, Ehret G, et al. Sociodemographic, behavioral and genetic determinants of allostatic load in a Swiss population-based study. Psychoneuroendocrinology. 2016 May;67:76-85.

229 Forrester SN, Leoutsakos JM, Gallo JJ, Thorpe RJ Jr, Seeman TE. Association between allostatic load and health behaviours: a latent class approach. J Epidemiol Community Health. 2019 Apr;73(4):340-5.

230 Clark AJ, Dich N, Lange T, Jennum P, Hansen AM, Lund R, et al. Impaired sleep and allostatic load: cross-sectional results from the Danish Copenhagen Aging and Midlife Biobank. Sleep Med. 2014 Dec;15(12):1571-8.

231 Upchurch DM, Rainisch BW, Chyu L. Greater leisure time physical activity is associated with lower allostatic load in White, Black, and Mexican American midlife women: findings from the National Health and Nutrition Examination Survey, 1999 through 2004. Womens Health Issues. 2015 Nov-Dec;25(6):680-7.

232 Bei B, Seeman TE, Carroll JE, Wiley JF. Sleep and physiological dysregulation: a closer look at sleep intraindividual variability. Sleep (Basel). 2017 Sep;40(9):Zsx109.

233 Hux VJ, Roberts JM, Okun ML. Allostatic load in early pregnancy is associated with poor sleep quality. Sleep Med. 2017 May;33: 85-90.

234 Mattei J, Noel SE, Tucker KL. A meat, processed meat, and French fries dietary pattern is associated with high allostatic load in Puerto Rican older adults. J Am Diet Assoc. 2011 Oct;111(10):1498-506.

235 Lee KH, Park SW, Ye SM, Kim SY, Kim SY, Han JS, et al. Relationships between dietary habits and allostatic load index in metabolic syndrome patients. Korean J Fam Med. 2013 Sep;34(5):334-46. 
236 Mattei J, Bhupathiraju S, Tucker KL. Higher adherence to a diet score based on American Heart Association recommendations is associated with lower odds of allostatic load and metabolic syndrome in Puerto Rican adults. J Nutr. 2013 Nov;143(11):1753-9.

237 van Draanen J, Prelip M, Upchurch DM. Consumption of fast food, sugar-sweetened beverages, artificially-sweetened beverages and allostatic load among young adults. Prev Med Rep. 2017 Nov;10(Nov):212-7.

238 Beydoun MA, Nkodo A, Fanelli-Kuczmarski MT, Maldonado AI, Beydoun HA, Popkin $\mathrm{BM}$, et al. Longitudinal associations between monetary value of the diet, DASH diet score and the allostatic load among middleaged urban adults. Nutrients. 2019 Oct; 11(10):2360

239 Ottino-González J, Jurado MA, García-García I, Caldú X, Prats-Soteras X, Tor E, et al. Allostatic load and executive functions in overweight adults. Psychoneuroendocrinology. 2019 Aug;106:165-70.

240 Gallo LC, Jiménez JA, Shivpuri S, Espinosa de los Monteros K, Mills PJ. Domains of chronic stress, lifestyle factors, and allostatic load in middle-aged Mexican-American women. Ann Behav Med. 2011 Feb;41(1):21-31.

241 Sotos-Prieto M, Bhupathiraju SN, Falcón LM, Gao X, Tucker KL, Mattei J. A healthy lifestyle score is associated with cardiometabolic and neuroendocrine risk factors among Puerto Rican adults. J Nutr. 2015 Jul; 145(7):1531-40.

242 Gillespie SL, Anderson CM, Zhao S, Tan Y, Kline D, Brock G, et al. Allostatic load in the association of depressive symptoms with incident coronary heart disease: The Jackson Heart Study. Psychoneuroendocrinology. 2019 Nov; 109:104369.

243 Sabbah W, Watt RG, Sheiham A, Tsakos G. Effects of allostatic load on the social gradient in ischaemic heart disease and periodontal disease: evidence from the Third National Health and Nutrition Examination Survey. J Epidemiol Community Health. 2008 May;62(5):415-20.

244 Nelson KM, Reiber G, Kohler T, Boyko EJ. Peripheral arterial disease in a multiethnic national sample: the role of conventional risk factors and allostatic load. Ethn Dis. 2007;17(4):669-75.

245 Porcelli P, Laera D, Mastrangelo D, Di Masi A. Prevalence of allostatic overload syndrome in patients with chronic cardiovascular disease. Psychother Psychosom. 2012; 81(6):375-7.

246 Offidani E, Rafanelli C, Gostoli S, Marchetti G, Roncuzzi R. Allostatic overload in patients with atrial fibrillation. Int J Cardiol. 2013 May;165(2):375-6.

247 Gostoli S, Bonomo M, Roncuzzi R, Biffi M, Boriani G, Rafanelli C. Psychological correlates, allostatic overload and clinical course in patients with implantable cardioverter defibrillator (ICD). Int J Cardiol. 2016 Oct;220: $360-4$.
248 Guidi J, Offidani E, Rafanelli C, Roncuzzi R, Sonino N, Fava GA. The assessment of allostatic overload in patients with congestive heart failure by clinimetric criteria. Stress Health. 2016 Feb;32(1):63-9.

249 Guidi J, Lucente M, Piolanti A, Roncuzzi R, Rafanelli C, Sonino N. Allostatic overload in patients with essential hypertension. Psychoneuroendocrinology. 2020 Mar; 113: 104545.

250 Matzer F, Fazekas C, Vajda C, Pilz S, Schwetz $\mathrm{V}$, Trummer C, et al. Association of allostatic load with health-related quality of life in patients with arterial hypertension: a crosssectional analysis. Swiss Med Wkly. 2018 Dec;148:w14689.

251 Steptoe A, Hackett RA, Lazzarino AI, Bostock S, La Marca R, Carvalho LA, et al. Disruption of multisystem responses to stress in type 2 diabetes: investigating the dynamics of allostatic load. Proc Natl Acad Sci USA. 2014 Nov;111(44):15693-8.

252 Carlsson AC, Nixon Andreasson A, Wändel PE. Poor self-rated health is not associated with a high total allostatic load in type 2 diabetic patients-but high blood pressure is. Diabetes Metab. 2011 Nov;37(5):446-51.

253 Allsworth JE, Weitzen S, Boardman LA. Early age at menarche and allostatic load: data from the Third National Health and Nutrition Examination Survey. Ann Epidemiol. 2005 Jul;15(6):438-44.

254 Hux VJ, Roberts JM. A potential role for allostatic load in preeclampsia. Matern Child Health J. 2015 Mar;19(3):591-7.

255 Hux VJ, Catov JM, Roberts JM. Allostatic load in women with a history of low birth weight infants: the national health and nutrition examination survey. J Womens Health (Larchmt). 2014 Dec;23(12):1039-45.

256 Accortt EE, Mirocha J, Dunkel Schetter C, Hobel CJ. Adverse perinatal outcomes and postpartum multi-systemic dysregulation: adding vitamin $\mathrm{D}$ deficiency to the allostatic load index. Matern Child Health J. 2017 Mar;21(3):398-406.

257 Shalowitz MU, Schetter CD, Hillemeier MM, Chinchilli VM, Adam EK, Hobel CJ, et al.; Eunice Kennedy Shriver National Institute of Child Human Development Community Child Health Network. Cardiovascular and metabolic risk in women in the first year postpartum: allostatic load as a function of race, ethnicity, and poverty status. Am J Perinatol. 2019 Aug;36(10):1079_ 89.

258 Morrison S, Shenassa ED, Mendola P, Wu T, Schoendorf K. Allostatic load may not be associated with chronic stress in pregnant women, NHANES 1999-2006. Ann Epidemiol. 2013 May;23(5):294-7.

259 Wallace M, Harville E, Theall K, Webber L, Chen W, Berenson G. Preconception biomarkers of allostatic load and racial disparities in adverse birth outcomes: the Bogalusa Heart Study. Paediatr Perinat Epidemiol. 2013 Nov;27(6):587-97.
260 Mori T, Karlamangla AS, Merkin SS, Crandall CJ, Binkley N, Greendale GA, et al. Multisystem dysregulation and bone strength: findings from the study of midlife in the United States. J Clin Endocrinol Metab. 2014 May;99(5):1843-51.

261 Goertzel BN, Pennachin C, de Souza Coelho L, Maloney EM, Jones JF, Gurbaxani B. Allostatic load is associated with symptoms in chronic fatigue syndrome patients. Pharmacogenomics. 2006 Apr;7(3):485-94.

262 Maloney EM, Gurbaxani BM, Jones JF, de Souza Coelho L, Pennachin C, Goertzel BN. Chronic fatigue syndrome and high allostatic load. Pharmacogenomics. 2006 Apr;7(3): $467-73$.

263 Maloney EM, Boneva R, Nater UM, Reeves WC. Chronic fatigue syndrome and high allostatic load: results from a populationbased case-control study in Georgia. Psychosom Med. 2009 Jun;71(5):549-56.

264 Smith AK, Maloney EM, Falkenberg VR, Dimulescu I, Rajeevan MS. An angiotensin-1 converting enzyme polymorphism is associated with allostatic load mediated by C-reactive protein, interleukin-6 and cortisol. Psychoneuroendocrinology. 2009 May; 34(4):597-606.

265 Leombruni P, Zizzi F, Pavan S, Fusaro E, Miniotti M. Allostatic overload in patients with fibromyalgia: preliminary findings. Psychother Psychosom. 2019;88(3):180-1.

266 Bay E, Covassin T. Chronic stress, somatic and depressive symptoms following mild to moderate traumatic brain injury. Arch Psychiatr Nurs. 2012 Dec;26(6):477-86.

267 Bay E, Donders J. Risk factors for depressive symptoms after mild-to-moderate traumatic brain injury. Brain Inj. 2008 Mar;22(3): 233-41.

268 Baldin E, Hauser WA, Pack A, Hesdorffer DC. Stress is associated with an increased risk of recurrent seizures in adults. Epilepsia. 2017 Jun;58(6):1037-46.

269 Cosci F, Svicher A, Romanazzo S, Maggini L, De Cesaris F, Benemei S, et al. Criterionrelated validity in a sample of migraine outpatients: the diagnostic criteria for psychosomatic research. CNS Spectr. 2019 Oct; $1-7$.

270 Abercrombie HC, Giese-Davis J, Sephton S, Epel ES, Turner-Cobb JM, Spiegel D. Flattened cortisol rhythms in metastatic breast cancer patients. Psychoneuroendocrinology. 2004 Sep;29(8):1082-92.

271 Parente V, Hale L, Palermo T. Association between breast cancer and allostatic load by race: National Health and Nutrition Examination Survey 1999-2008. Psychooncology. 2013 Mar;22(3):621-8.

272 Ruini C, Offidani E, Vescovelli F. Life stressors, allostatic overoad and their impact on posttraumatic growth. J Loss Trauma. 2015; 20(2):109-22. 
273 Ye ZJ, Qiu HZ, Liang MZ, Liu ML, Li PF, Chen P, et al. Effect of a mentor-based, supportive-expressive program, Be Resilient to Breast Cancer, on survival in metastatic breast cancer: a randomised, controlled intervention trial. Br J Cancer. 2017 Nov; 117(10):1486-94.

274 Borrell LN, Crawford ND. Social disparities in periodontitis among US adults: the effect of allostatic load. J Epidemiol Community Health. 2011 Feb;65(2):144-9.

275 Masterson EE, Sabbah W. Maternal allostatic load, caretaking behaviors, and child dental caries experience: a cross-sectional evaluation of linked mother-child data from the third National Health and Nutrition Examination Survey. Am J Public Health. 2015 Nov;105(11):2306-11.

276 Tomba E, Offidani E. A clinimetric evaluation of allostatic overload in the general population. Psychother Psychosom. 2012;81(6): 378-9.

277 Offidani E, Ruini C. Psychobiological correlates of allostatic overload in a healthy population. Brain Behav Immun. $2012 \mathrm{Feb}$; 26(2):284-91.

278 Piolanti A, Gostoli S, Gervasi J, Sonino N, Guidi J. A trial integrating different methods to assess psychosocial problems in primary care. Psychother Psychosom. 2019;88(1): 30-6.

279 Juster RP, Marin MF, Sindi S, Nair NP, Ng YK, Pruessner JC, et al. Allostatic load associations to acute, 3-year and 6-year prospective depressive symptoms in healthy older adults. Physiol Behav. 2011 Aug;104(2): 360-4.

280 Kobrosly RW, van Wijngaarden E, Seplaki CL, Cory-Slechta DA, Moynihan J. Depressive symptoms are associated with allostatic load among community-dwelling older adults. Physiol Behav. 2014 Jan;123:223-30.

281 Kuhn M, Scharfenort R, Schümann D, Schiele MA, Münsterkötter AL, Deckert J, et al. Mismatch or allostatic load? Timing of life adversity differentially shapes gray matter volume and anxious temperament. Soc Cogn Affect Neurosci. 2016 Apr;11(4):53747.

282 Bey GS, Waring ME, Jesdale BM, Person SD. Gendered race modification of the association between chronic stress and depression among Black and White U.S. adults. Am J Orthopsychiatry. 2018;88(2):151-60.

283 Juster RP, Sasseville M, Giguère CE, Consortium S, Lupien SJ. Elevated allostatic load in individuals presenting at psychiatric emergency services. J Psychosom Res. 2018 Dec; 115:101-9.

284 Bay E, Kirsch N, Gillespie B. Chronic stress conditions do explain posttraumatic brain injury depression. Res Theory Nurs Pract. 2004;18(2-3):213-28.
285 Rodriquez EJ, Livaudais-Toman J, Gregorich SE, Jackson JS, Nápoles AM, Pérez-Stable EJ. Relationships between allostatic load, unhealthy behaviors, and depressive disorder in U.S. adults, 2005-2012 NHANES. Prev Med. 2018 May;110:9-15.

286 Adynski H, Zimmer C, Thorp J Jr, Santos HP Jr. Predictors of psychological distress in low-income mothers over the first postpartum year. Res Nurs Health. 2019 Jun;42(3): 205-16.

287 Scheuer S, Wiggert N, Brückl TM, Awaloff Y, Uhr M, Lucae S, et al. Childhood abuse and depression in adulthood: the mediating role of allostatic load. Psychoneuroendocrinology. 2018 Aug;94:134-42.

288 Gale CR, Batty GD, Cooper SA, Deary IJ, Der G, McEwen BS, et al. Reaction time in adolescence, cumulative allostatic load, and symptoms of anxiety and depression in adulthood: the West of Scotland Twenty-07 Study. Psychosom Med. 2015 Jun;77(5): 493-505.

289 Vaccarino SR, Rajji TK, Gildengers AG, Waters SE, Butters MA, Menon M, et al. Allostatic load but not medical burden predicts memory performance in late-life bipolar disorder. Int J Geriatr Psychiatry. 2018 Mar; 33(3):546-52.

290 Li Y, Rosemberg MS, Seng JS. Allostatic load: A theoretical model for understanding the relationship between maternal posttraumatic stress disorder and adverse birth outcomes. Midwifery. 2018 Jul;62:205-13.

291 Glover DA. Allostatic load in women with and without PTSD symptoms. Ann N Y Acad Sci. 2006 Jul;1071(1):442-7.

292 Glover DA, Stuber M, Poland RE. Allostatic load in women with and without PTSD symptoms. Psychiatry. 2006;69(3):191-203.

293 Thayer Z, Barbosa-Leiker C, McDonell M, Nelson L, Buchwald D, Manson S. Early life trauma, post-traumatic stress disorder, and allostatic load in a sample of American Indian adults. Am J Hum Biol. 2017 May; 29(3): 10 .

294 Beckie TM, Duffy A, Groer MW. The relationship between allostatic load and psychosocial characteristics among women veterans. Womens Health Issues. 2016 Sep-Oct; 26(5):555-63.

295 Chiappelli J, Kochunov P, Savransky A, Fisseha F, Wisner K, Du X, et al. Allostatic load and reduced cortical thickness in schizophrenia. Psychoneuroendocrinology. 2017 Mar;77:105-11.

296 Savransky A, Chiappelli J, Rowland LM, Wisner K, Shukla DK, Kochunov P, et al. Fornix structural connectivity and allostatic load: empirical evidence from schizophrenia patients and healthy controls. Psychosom Med. 2017 Sep;79(7):770-6.

297 Savransky A, Chiappelli J, Fisseha F, Wisner KM, Xiaoming D, Mirmomen SM, et al. Elevated allostatic load early in the course of schizophrenia. Transl Psychiatry. 2018 Nov; 8(1):246.
298 Nugent KL, Chiappelli J, Rowland LM, Hong LE. Cumulative stress pathophysiology in schizophrenia as indexed by allostatic load. Psychoneuroendocrinology. 2015 Oct; 60:120-9.

299 Berger M, Juster RP, Westphal S, Amminger GP, Bogerts B, Schiltz K, et al. Allostatic load is associated with psychotic symptoms and decreases with antipsychotic treatment in patients with schizophrenia and first-episode psychosis. Psychoneuroendocrinology. 2018 Apr;90:35-42.

300 Misiak B, Kotowicz K, Loska O, Stramecki F, Beszłej JA, Samochowiec J, et al. Decreased use of active coping styles contributes to elevated allostatic load index in first-episode psychosis. Psychoneuroendocrinology. 2018 Oct;96:166-72.

301 Piotrowski P, Kotowicz K, Rymaszewska J, Beszłej JA, Plichta P, Samochowiec J, et al. Allostatic load index and its clinical correlates at various stages of psychosis. Schizophr Res. 2019 Aug;210:73-80.

302 Adinoff B, Leonard D, Price J, Javors MA, Walker R, Brown ES, et al. Adrenocortical sensitivity, moderated by ongoing stress, predicts drinking intensity in alcohol-dependent men. Psychoneuroendocrinology. 2017 Feb;76:67-76.

303 Kroenke K. A practical and evidence-based approach to common symptoms: a narrative review. Ann Intern Med. 2014 Oct;161(8): $579-86$.

304 Henningsen P, Zipfel S, Sattel H, Creed F. Management of functional somatic syndromes and bodily distress. Psychother Psychosom. 2018;87(1):12-31.

305 Goldwater DS, Dharmarajan K, McEwan BS, Krumholz HM. Is posthospital syndrome a result of hospitalization-induced allostatic overload? J Hosp Med. 2018 May; 13(5). https://doi.org/10.12788/jhm.2986.

306 Sonino N, Fava GA. Improving the concept of recovery in endocrine disease by consideration of psychosocial issues. J Clin Endocrinol Metab. 2012 Aug;97(8):2614-6.

307 Offidani E, Tomba E, Linder MD. Two key concepts in the life course approach in medicine: allostatic load and cumulative life course impairment. Curr Probl Dermatol. 2013;44:17-32.

308 McEwen BS. Protection and damage from acute and chronic stress: allostasis and allostatic overload and relevance to the pathophysiology of psychiatric disorders. Ann N Y Acad Sci. 2004 Dec;1032(1):1-7.

309 Bizik G, Picard M, Nijjar R, Tourjman V, McEwen BS, Lupien SJ, et al. Allostatic load as a tool for monitoring physiological dysregulations and comorbidities in patients with severe mental illnesses. Harv Rev Psychiatry. 2013 Nov-Dec;21(6):296-313.

310 Theorell T. COVID-19 and working conditions in health care. Psychother Psychosom. 2020;89(4):193-4. 
311 Zhang WR, Wang K, Yin L, Zhao WF, Xue $\mathrm{Q}$, Peng M, et al. Mental health and psychosocial problems of medical health workers during the COVID-19 epidemic in China. Psychother Psychosom. 2020;89(4):242-50.

312 Danese A, McEwen BS. Adverse childhood experiences, allostasis, allostatic load, and age-related disease. Physiol Behav. 2012 Apr;106(1):29-39.

313 Theorell T. Regeneration and anabolism: the good perspective. In: Theorell $\mathrm{T}$, editor. Handbook of Socioeconomic determinants of occupational health. Dordrecht: Springer; 2020. p. 1-13.

314 McEwen BS. Epigenetic interactions and the brain-body communication. Psychother Psychosom. 2017;86(1):1-4.

315 Fava GA, Rafanelli C. Iatrogenic factors in psychopathology. Psychother Psychosom. 2019;88(3):129-40.
316 Rippe JM. Are we ready to practice lifestyle medicine? Am J Med. 2019 Jan;132(1):6-8.

317 Fava GA, Guidi J. The pursuit of euthymia. World Psychiatry. 2020 Feb;19(1):40-50.

318 Fava GA. Well-Being Therapy. Treatment manual and clinical applications. Basel: Karger; 2016. https://doi.org/10.1159/isbn. 978-3-318-05822-2.

319 Lindsäter E, Axelsson E, Salomonsson S, Santoft F, Ejeby K, Ljótsson B, et al. Internetbased cognitive behavioral therapy for chronic stress: a randomized controlled trial. Psychother Psychosom. 2018;87(5):296305.

320 von Brachel R, Hirschfeld G, Berner A, Willutzki U, Teismann T, Cwik JC, et al. Longterm effectiveness of cognitive behavioral therapy in routine outpatient care: a 5- to 20year follow-up study. Psychother Psychosom. 2019;88(4):225-35.
321 Lobitz G, Armstrong K, Concato J, Singer $\mathrm{BH}$, Horwitz RI. The biological and biographical basis of precision medicine. Psychother Psychosom. 2019;88(6):333-40.

322 Carrozzino D, Svicher A, Patierno C, Berrocal C, Cosci F. The Euthymia scale: a clinimetric analysis. Psychother Psychosom. 2019;88(2):119-21.

323 Szyf M. The epigenetics of perinatal stress. Dialogues Clin Neurosci. 2019 Dec;21(4): 369-78.

324 Sonino N, Peruzzi P. A psychoneuroendocrinology service. Psychother Psychosom. 2009;78(6):346-51.

325 van Schijndel MA, Jansen LA, van de Klundert JJ. Empirical types of medical psychiatry units. Psychother Psychosom. 2019;88(2): $127-8$. 